\title{
From the age of the pyramids to the superfast world - what has changed in the management of spinal injuries?
}

\author{
Sreedhar Kolli, Clive Inman and ] Chowdhury
}

Spinal cord injury (SCI) can be life changing and is associated with a variable prognosis. The descriptions of symptoms of the injury are as old as the pyramids, probably among the earliest case records are from the Edwin Smith Surgical papyrus that dates back to 2500-3500 BC. In that day and age it was considered 'an ailment not to be cured [treated]'. However, in the 21st century things are viewed differently. The quality of life, morbidity, mortality and participation in employment and sports following spinal injuries have been revolutionised by understanding the pathology and setting standards and principles of management of care pioneered by Sir Ludwig Guttmann during the second world war who established the first spinal injuries centre at Stoke Mandeville in 1944. The principles have been replicated all over the world and have led to much improved outcomes in patients with spinal injuries. The current annual incidence of spinal injuries in the UK is $10-15$ per million population. ${ }^{1}$

A symposium was organised a tribute to the last student of Sir Ludwig Guttmann, Professor Wagih Shafik El-Masri on as his 65 th birthday. This was organised by his colleagues at the Midlands Centre for Spinal Injuries, Robert Jones and Agnes Hunt Orthopaedic Hospital and attended by 150 delegates (colleagues and friends of Professor El Masri). Guest speakers were invited from various parts of the world. The forum discussed various important learning points and observations from eminent professors in the field of spinal injuries where there is a dearth of level 1 evidence in many aspects of care. This forum also discussed various research projects on the horizon. The need for improved standards of SCI training across Europe was also highlighted.

Professor Hans Frankel, an eminent neurologist from Stoke Mandeville discussed his ideas and the origins of the Frankel classification which is widely used in the classification of neurological deficit in SCI. ${ }^{2}$ The Medical Research Council (MRC) scale was ordinal only and failed to demonstrate the functional deficit. His classification eliminated observer bias by recording functional abilities, though today, the version used in day-to-day practice tends to be the ASIA scale of impairment which also includes sacral sparing on initial examination. He also opined

Sreedhar Kolli, consultant in spinal injuries, Rookwood Hospital, Cardiff; Clive Inman, consultant in spinal injuries, Rookwood Hospital, Cardiff; Joy Chowdhury, specialist registrar and consultant in spinal injuries, Midland Centre for Spinal Injuries, Oswestry

This article is based on a spinal cord symposium, which was held on 11 March 2011 at the Institute of Orthopaedics, Robert Jones and Angnes Hunt Orthopaedic and District Hospital, Oswestry that regular digital per rectal examination may not add more information than performing a perineal pin prick examination. He concluded that in his experience, managing spinal injuries is easy but not simple. He suggested that electrical perceptual threshold based on skin resistance is the quantitative way of measuring sensation though currently this is mainly used for research purposes. ${ }^{3}$

Geoffrey Raisman, professor of neural regeneration at University College, London, discussed the repair of spinal cord and spinal root injuries by transplantation of cultured adult olfactory ensheathing cells. He emphasised that it was the connection pathways which needed to be addressed as every living creature in nature has a potential to regrow. In the nervous system the synapses and pathways need to be improved for a meaningful recovery. He illustrated the regeneration pattern of recovery of spinal cord injured rats. ${ }^{4}$

Professor Anthony Ward from the University of North Staffordshire praised the role of Professor El Masri in setting up excellent training and standards for trainees in rehabilitation medicine, not only in the UK but also across Europe in various aspects of spinal care. He strongly encouraged all the trainees to take the European board examination for physical medicine and rehabilitation.

Professor S Katoh, a spinal surgeon from Japan, presented the research work he had done with Professor El Masri on prognostic indicators for recovery of various incomplete spinal injuries within one year of discharge. ${ }^{5,6} \mathrm{He}$ concluded that there is no level 1 evidence that spinal surgery in trauma enhances outcomes and there is only level 3 evidence that spinal fracture reduction and traction would improve outcome. He stated that there is no correlation between the extent of neurological recovery and the degree of malalignment, degree of spinal canal stenosis/encroachment on computed tomography scan or cord compression on magnetic resonance imaging. ${ }^{7}$ It was emphasised that to date there is no evidence that surgery improves the neurologica outcome of spinal injury. He also commented that not all cervical fractures can be stabilised with the Halo jacket.

Professor Christopher Mathias, eminent neurologist from Imperial College, London, spoke on cardiovascular autonomic dysfunction in spinal injury. He spoke about new research in the treatment of autonomic dysreflexia including ideas of immune modulation with drugs. His research contributed to the enhanced understanding of autonomic nervous system dysfunction. $^{8}$

Dr Justin Brown, a neurosurgeon with a special interest in reconstruction of peripheral nerve injuries from the USA, 


\section{Conference programme}

Frankel classification: how it started and what came next Professor H Frankel, Stoke Mandeville Hospital

Cell transplantation for spinal cord repair

Professor Geoffrey Raisman, University College London

European perspective for training in spinal cord rehabilitation Professor Anthony Ward, University of North Staffordshire

Prognostic indicators for spinal cord injury

Dr S Katoh, Japan

Cardiovascular autonomic dysfunction in spinal cord injury

Professor Christopher Mathias, Imperial College, London

Surgical repair of peripheral nerve injuries and implications to improve upper limb function in tetraplegia

Dr Justin Brown, St Louis, USA

Specialised centers for spinal cord injury - differences between the developed and developing countries

Dr A Kovindha, Thailand

Guttman, Frankel, El Masri and what afterwards?

Professor D Wang, China

emphasised various options of neural transplantation to improve upper limb function in patients with tetraplegia. Professor A Kovindha from Thailand described the differences in care required in developing countries and the difficulties of introducing innovations in care in specialised centres, especially long-term care.

Professor Wang from China emphasised the struggle Howard Rusk had in convincing the American authorities about the need for rehabilitation. Dr Rusk received no respect from his colleagues for the practice of rehabilitation. However, in the UK, understanding the pathology and innovations in technology formed the basis for the growth and survival of the specialty.

Prof Avi Ohry from Israel and Dr Anton paid tribute to Professor El Masri for his contribution to understanding the physiological instability of the spinal cord, which is important in the early management and reiterated the importance of conservative management and the limited role for surgery in spinal injuries.

Professor JJ Wyndaele, consultant urologist from Belgium and chief editor of Spinal Cord, highlighted Professor El Masri's valued contribution to the literature on so many aspects of spinal injury. ${ }^{9-15}$

\section{Conclusion}

Clinical features of SCI were first described in Egyptian manuscripts, but in the 21 st century there is no breakthrough in curing such injuries. However, understanding the pathophysiology to provide adequate management from injury, regular surveillance, timely intervention if complications arise and innovations in technology for independent living have significantly enhanced the quality of life and limited the morbidity and mortality of patients living with spinal injuries. Research in cell technologies may be a future hope.

\section{References}

1 Grundy D, Swain A. ABC of spinal cord injury, 4th edn. London: BMJ Books, 2002:1.

2 Frankel HL, Hancock DO, Hyslop G et al. The value of postural reduction in the initial management of closed injuries of the spine with paraplegia and tetraplegia. Paraplegia 1969;7:179-92.

3 King NK, Savic G, Frankel H, Jamous A, Ellaway PH. Reliability of cutaneous electrical perceptual threshold in the assessment of sensory perception in patients with spinal cord injury. J Neurotrauma 2009;26:1061-8.

4 Raisman G, Li Y. Repair of neural pathways by olfactory ensheathing cells. Nature Reviews Neuroscience 2007;8:312-19.

5 Katoh S, el Masry WS, Jaffray D et al. Neurologic outcome in conservatively treated patients with incomplete closed traumatic cervical spinal cord injuries. Spine (Phila Pa 1976) 1996;21:2345-51.

6 Katoh S, El Masri WS. Motor recovery of patients presenting with motor paralysis and sensory sparing following cervical spinal cord injuries. Paraplegia 1995;33:506-9.

7 El Masri WS, Katoh S, Khan A. Reflections on the neurological significance of bony canal encroachment following traumatic injury of the spine in patients with Frankel C D and E presentation. J Neurotrauma 1993;10(Suppl):70.

8 Mathias CJ. Autonomic diseases: clinical features and laboratory evaluation. J Neurol Neurosur 2003;74:III31-III41.

9 El Masri WS. Management of traumatic spinal cord injuries: current standard of care revisited. ACNR 2010;10:37-40.

10 El Masry WS. Traumatic spinal cord injury: the relationship between pathology and clinical implications. Trauma 2006;8:29-46.

11 El Masry WS, Biyani A. Incidence, management and outcome of post traumatic syringomyelia. J Neurol Neurosurg Psych 1996;60:141-6.

12 Ibrahim A, Li Y, Li D, Raisman G, El Masry WS. Olfactory ensheathing cells: ripples of an incoming tide? Lancet Neurol 2006;5:453-7.

13 El Masri WS, Jaffray DJ. Recent developments in the management of injuries of the cervical spine. In: Frankel HL (ed.), Spinal cord trauma. Amsterdam: Elsevier, 1992:55-73.

14 Folman Y, El Masri WS. Spinal cord injury: prognostic indicators. Injury 1989;20:92-3.

15 El Masri WS, Fellows G. Bladder cancer after spinal cord injury. Paraplegia 1981;19:265-70.

Address for correspondence: Dr S Kolli, Rookwood Hospital, Fairwater Road, Llandaff, Cardiff CF5 2YN.

Email: drkollisridhar2@hotmail.com 